\title{
Paulus og neurobiologien
}

\author{
Professor, dr.theol. Troels Engberg-Pedersen
}

Colleen Shantz, Paul in Ecstasy: The Neurobiology of the Apostle's Life and Thought Cambridge: Cambridge University Press 2009. 267 s. $£ 45$.

Abstract: This review discussion of Colleen Shantz, Paul in Ecstasy etc. describes the main argument of the book, criticizes various details of its argumentation and concludes with a general assessment, which basically applauds the focus on 'religious experience' and the attempt to bring in both contemporary neuroscience and social anthropology to elucidate Paul and Pauline Christianity, but also queries whether these modern disciplines are at present sufficiently precise for it to be possible to draw any firm conclusions regarding the historical material.

Key words: Paul - religious experience - ecstasy - trance - neuroscience - social anthropology - soul journey - mysticism - spirit possession shamanism - mediumship.

Colleen Shantz' bog er både dristig og spændende. Den forsøger at udvide forståelsen af Paulus ret voldsomt ved at inddrage indsigter, der er gjort i de sidste par årtier vedr. fænomenet 'religiøs erfaring' ("religious experience") inden for moderne neurovidenskab eller kognitionsforskning og moderne socialantropologi, og applicere dem på Paulus. Derved forsøger den både at kaste nyt eksegetisk lys over Paulusteksterne selv og også at formulere en ny overordnet forståelse af, hvad tidlig kristen religion i dens paulinske udformning overhovedet var for en type religion. Men bogen er også fuld af problemer.

\section{Religiøs erfaring som grundkategori}

Bogen er på den ene side erklæret interdisciplinær, på den anden side fokuserer den meget præcist hele vejen igennem på ét bestemt fænomen: 'religiøs erfaring'. Dette fokus artikuleres specielt i det indledende metodekapitel (kap. 1). Her er hovedlinjen, at begrebet har været ugleset i Paulus-forskningen, dels fordi man af teologiske grun- 
de ville undgå enhver 'psykologisering' af apostlen, dels fordi man i den del af humaniora, der falder under 'the linguistic turn' (i sidste halvdel af det 20. årh.), grundlæggende mente, at "there is no experience apart from linguistic construction of it" (56). Heroverfor argumenterer Shantz for, at der er menneskelige fænomener - og som det viser sig: grundlæggende i hjernen - som går forud for artikuleringen i sproget. 'Kulturen', som jo er forskellig fra sted til sted og tid til tid, er rigtignok med til at levere de sproglige kategorier, hvori erfaringen fortolkes. Men der er før-sproglige fænomener, som netop er dem, sproget forsøger at artikulere.

Enhver, der har fulgt diskussionen af fænomenet religiøs erfaring gennem de sidste 30-40 år, vil vide, at Shantz her stikker hånden i en hvepserede. Men det er hun nødt til for at kunne fă fat i den grundlæggende størrelse, som hun ønsker at udarbejde betydningen af: en type fænomen, der foreligger reelt i verden (nemlig som det viser sig: i hjernen), og som Paulus så forsøgte at artikulere, som bedst han kunne.

\section{Neurovidenskab i nutid og fortid}

Kap. 2 giver så et grundkursus, dels i udviklingen af den menneskelige hjerne, dels i en bestemt moderne teori om 'ekstase' ("ecstasy"), trance ("trance") eller 'ændret bevidsthedstilstand' ("altered state of consciousness" - ASC) - alt sammen begreber, som Shantz med overlæg benytter mere eller mindre synonymt (19). For det første emne bygger hun på en række anerkendte amerikanske hjerneforskere (bl.a. Rhawn Joseph). For det andet bygger hun primært på Eugene d'Aquili og Andrew Newbergs velkendte bog om The Mystical Mind fra 1999. Lad det være sagt med det samme, at denne anmelder ikke er i stand til at vurdere disse teorier indefra. Men det virker, som om Shantz har gjort sit hjemmearbejde med at sætte sig ind i en række forskeres arbejder på feltet, som de facto hører til i frontlinjen.

I resten af kapitlet vender Shantz sig til en applikation af de moderne teorier på 2 Kor 12,1-4. Hun argumenterer her for, at Paulus i to tilfælde i denne berømte skildring af hans egen himmelrejse taler på en måde, som forstås bedst, hvis man forudsætter, at han er i færd med at finde ord for en oplevelse, der forelå for ham på forhånd, om ikke andet som en begivenhed i hjernen. (Bemærk her, at Shantz slet ikke tager stilling til, at Paulus selv jo taler om en egentlig himmelsrejse, han skal have foretaget. Man kan fuldt ud forstå, hvorfor hun lader denne dimension ligge. Men det er og bliver dog besynderligt, at sagen slet ikke nævnes.) De to steder er dels hans gentagne påstand 
om, at han selv ikke ved (kun Gud ved det!), om han foretog sin himmelrejse " $\mathrm{i}$ kroppen eller uden for kroppen", dels hans påstand om at have hørt "uudsigelige ord, som et menneske ikke må udtale" (DO 1992).

Hvad det første angår, ser det - når man kommer fra neurovidenskaben - ud, som om Paulus her forsøger at artikulere en bestemt hjernetilstand, som man kender fra moderne religiøse "ecstatics", og som er forskellig fra den normale. Uanset, hvordan man nærmere skal fortolke oplevelsen både neuro- og fænomenologisk, tror jeg, man må give Shantz ret i, at Paulus faktisk er i færd med at artikulere en religiøs erfaring.

Hvad det andet tema angår, argumenterer Shantz med yderligere neurovidenskabeligt input for, at de ord, Paulus hørte, var 'uudsigelige' i den forstand, at de hverken kunne eller kan udsiges. Og sådan forstår hun også det græske ord ' '̧̧óv i Paulus' lille tilføjelse, som DO 1992 har oversat "som et menneske ikke må udtale". Her skulle man if. Shantz snarere oversætte "som et menneske ikke kan udtale". Det er nemlig ikke Paulus' venstre hjernehalvdel, der har været aktiv i denne oplevelse, men den højre (106)! Har Shantz ret rent eksegetisk? Spørgsmålet kan ikke besvares på en studs, men hendes afvisning $(107, \mathrm{n} .135)$ af at lade sig inspirere af den eneste anden brug hos Paulus (fx i 1 Kor 6,12) af det involverede verbum, som peger i retning af 'må' frem for 'kan', er ikke overbevisende. Og jeg forbliver skeptisk.

\section{Eksegese ud over alle grænser}

Med sin neurologiske fortolkning af 2 Kor 12,1-4 på plads kaster Shantz i kap. 3 sit net ud over hele det paulinske corpus. Hun søger at vise, at der er en lang række temaer hos Paulus, som åbner sig for en neurologisk fortolkning. Fx taler han jo i 2 Kor 12,1 om 'syner og åbenbaringer', jf. fx 1 Kor 9,1 og 15,8 eller Gal 1,11-12 og 2,2. Og

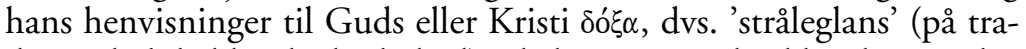
ditionelt bibeldansk: herlighed), skal givetvis udtrykke det, Paulus rent faktisk så. I alle disse tilfælde forestiller Shantz sig, at Paulus har været i trance eller ekstase.

Eller tag to længere passager som 2 Kor 3-5 og Rom 8. Her optræder der også en lang række begreber, som på den ene eller den anden

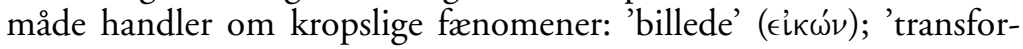

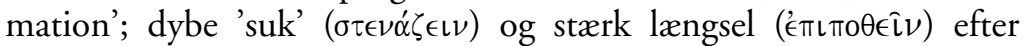
transformationen; og endelig bruges selve termen for 'ekstase' ( $k \xi \hat{i}$ $\left.\sigma \tau \alpha^{\prime} \nu \alpha \iota\right)$ om Paulus' forhold til Gud. Der er ikke her nødvendigvis tale 
om henvisninger til nogen bestemt begivenhed. Men "Paul slides into a fluid mingling of all these notions because they are neurologically connected in all of us" (127).

Shantz mener også at kunne finde spor af en særlig sammenhæng mellem ekstase og lidelse, fordi disse to erfaringer gentagne gange optræder sammen i de paulinske tekster. Eller tag en tekst som 2 Kor 4,10-11 om, hvordan Paulus "bærer rundt" på Jesu død i sit eget kød for at også Jesu liv kan blive åbenbaret i hans dødelige krop. Handler det ikke om ekstase? I begge tilfælde er jeg skeptisk, og det er i hvert fald sikkert, at Shantz ikke gør tilstrækkeligt ud af, hvad Paulus selv rent faktisk ville sige, når han talte om lidelse og at have Jesu død i sit eget kød. Derimod har hun absolut ret i, at Paulus taler om krop, blot ikke nødvendigvis som en refleks af en eller anden hjernebegivenhed.

Derudover er der de mange steder, hvor Paulus taler om at være 'i' Kristus og om en 'enhed' ("union”) med ham. Her må jeg nøjes med at give en henvisning til Shantz' udredning (137-138). Endelig er der ideen om at "embody death": at være korsfæstet sammen med Kristus (Gal 2,19-20), ligedannet med ham i hans død (Phil 3,10) og begravet med Kristus gennem dåben til døden (Rom 6,4) o.l. Også her finder Shantz et neurologisk korrelat (141).

Det er ikke muligt her at tage detaljeret stilling til disse forskellige forslag. Blot må det nok konstateres, at Shantz' vilje til at finde direkte fingerpeg om hjernebegivenheder hos Paulus er adskilligt stærkere, end teksterne reelt kan bære.

\section{Socialantropologiske trancestudier og Paulus og korintherne}

I det sidste hovedkapitel (kap. 4) vender Shantz så blikket fra Paulus selv til hans adressater og dermed hele den sociale kontekst for hans omfattende spillen på sine egne ekstatiske erfaringer. Som i kap. 2 bygger hun også her på input fra andre discipliner end bibelvidenskaben, her specielt den østrigsk-amerikanske antropolog Erika Bourguignon, som fra 1960'erne og frem skrev om forskellige former for trance i en lang række kulturer verden over, og den amerikanske antropolog Michael Winkelman, som ikke mindst har forsøgt at korrelere forskellige typer trance med forskellige typer samfund og forskellige sociale funktioner i de forskellige samfundstyper. Læseren skal her holde tungen meget lige i munden for at holde de forskellige typer trance klart adskilt fra hinanden - og endnu mere: at holde dem ligeså klart sammen med de forskellige typer samfund og funktioner i dem. Og endnu sværere bliver det naturligvis, når teorierne så skal appliceres på Paulus. 
Shantz vil undersøge de sociale dimensioner af tre forskellige typer trance, som Paulus synes at spille på i de to Korintherbreve: "spirit possession" hos korintherne, nemlig de facto deres tungetale (glossolali); "shamanism" hos Paulus selv, nemlig hans særlige rolle i forhold til korintherne i forbindelse med de forskellige former for trance, han oplevede; og endelig "mediumship" hos både Paulus og korintherne, som Shantz specielt forbinder med den type 'profeti', som Paulus taler så varmt for i 1 Kor 14.

Lad os nøjes med den midterste af de tre typer trance: Var Paulus en shaman? Og brugte han sine egne "ecstatic states" som en "social commodity" (176) i forbindelse med sit krav på en særlig status som apostel? Diskussionen af "shamanism" er til det yderste kompleks. På den ene side hævder Shantz (sikkert helt rigtigt), at "the term [nl. "shamanism"] is so tangled up in the politics of its misuse ... that it has become nearly impossible to use it helpfully" (147 n. 3). I stedet vil hun tale om "soul journey". Tilsvarende erklærer hun: "Paul was not a shaman" (147, se også s. 176). På den anden side: "when the category of shamanism is used to distinguish social roles, it can be a very helpful model because it provides a means to measure ecstatic states as a social commodity" (176). Og sådan kører det frem og tilbage (se også s. 182 og 184).

Hvad skal man sige om det? Jeg tror dette: Man kan sagtens lade sig inspirere af indsigter i moderne shamaners sociale funktioner til at få øje på noget tilsvarende hos Paulus. Men det er og bliver potentielt vildledende direkte at se Paulus som en shaman. Så det skal man nok lade være med.

\section{Noget er godt, noget er stadig meget mangelfuldt}

Selve Shantz' projekt er al ære værd. Det er klart, at der er fuldt af problemer, men hun har ret i sin principielle påstand om, at et veldefineret moderne begrebsapparat kan bruges til at få adgang til Paulus' 'mind' via hans egne tekster.

Shantz har også ret i at fokusere på begrebet 'religiøs erfaring'. Det har jeg selv gjort i min seneste bog om Paulus: Cosmology and Self in the Apostle Paul: The Material Mind (Oxford University Press, 2010). Og jeg synes, hans tekst tvinger en til det.

Det er også helt i orden at postulere tilstedeværelsen af et gab mellem, hvad der faktisk kan tænkes at være foregået i Paulus' hjerne (noget, der i princippet kan beskrives "cross-culturally" med de begreber, som den moderne neurovidenskab nu måtte udarbejde), og 
de meget mere kulturelt bestemte forsøg på at artikulere og beskrive det, som man finder hos Paulus selv.

I det hele taget er Shantz' understregning af Paulus' stadige brug af "body language" (mit udtryk) helt på sin plads. Jeg har selve fokuseret på det samme i den nævnte bog. Og jeg er ganske enig i, at man slet ikke får fat $\mathrm{i}$, hvad Paulus vil sige og udtrykke, hvis ikke man får alt dette med.

Derimod er jeg meget skeptisk over for muligheden af at korrelere med den nødvendige præcision, hvad Paulus siger, med denne eller hin moderne type af trance eller "ecstatic experience" forstået som noget, der kan beskrives præcist i termer, der vedrører hjernen. Årsagen er først og fremmest, at neurovidenskaben, så vidt jeg kan forstå, stadig er meget langt fra at kunne korrelere bestemte hjernesammenhænge med bestemte typer ASC. I min egen bog diskuterer jeg noget helt andet, nemlig Paulus' stadig kredsen om pneumaen. Og jeg forestiller mig, at han i mange tilfælde taler om en personlig 'religiøs erfaring' af at være taget kropsligt i besiddelse af netop pneumaen. Dette ligner på den ene side meget, hvad Shantz er ude efter. På den anden side er det fuldstændig forskelligt fra det, da jeg slet ikke taler specielt om hjernen.

Jeg er endnu mere skeptisk over for Shantz' forsøg på at korrelere forskellige typer trance (med tilhørende hjernesubstrat) med forskellige samfundstyper og sociale funktioner. Hendes (godt nok korte: 155-157) beskrivelse af, hvordan byen Korinth netop havde "the kind of profile typical of possession societies" (157) er efter min mening pure opspind. Og en tabel som den, man finder på s. 173-174 (overtaget fra Winkelman) over såkaldte "characteristics" af tre typer "magico-religious practitioners" (nemlig "the shaman", "the medium" og "the priest") i henseende til "Societal conditions", "Magicoreligious activity", "Sociopolitical power", "Social characteristics", "Selection and training", "Social context" og "Special skills/techniques" - sådan en tabel tror jeg simpelthen ikke på.

Det korte af det lange er da dette: Forsøget er godt og skal videreføres. Men der er meget lang vej igen, før der kan komme noget rigtig solidt ud af det.

Til allersidst kan man med rette spørge, hvad alt dette da kan betyde 'teologisk': Har det nogen som helst betydning for, hvad vi selv vil sige om verden i lyset af Paulus' tekst? At diskutere det spørgsmål ordentligt ville kræve en hel artikel. Men én pointe bliver i hvert helt tydelig, hvis man anlægger Shantz' (eller for den sags skyld mit eget) perspektiv på Paulus. Den pointe gør sig bedst på engelsk: religion is real. 